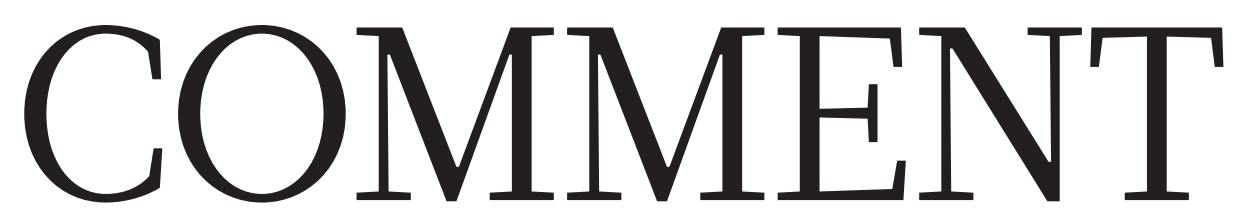

CLIMATE Replace $2^{\circ} \mathrm{C}$ warming goal with meaningful vital signs p.30
INNOVATION A chronicle of the teamwork that drove the digital revolution $\mathbf{p . 3 2}$
EVoLUTION Model shows it is a short step from squid to albatrosses p.34
AgEING Study optimism and resilience as well as physical decline $\mathbf{p . 3 5}$

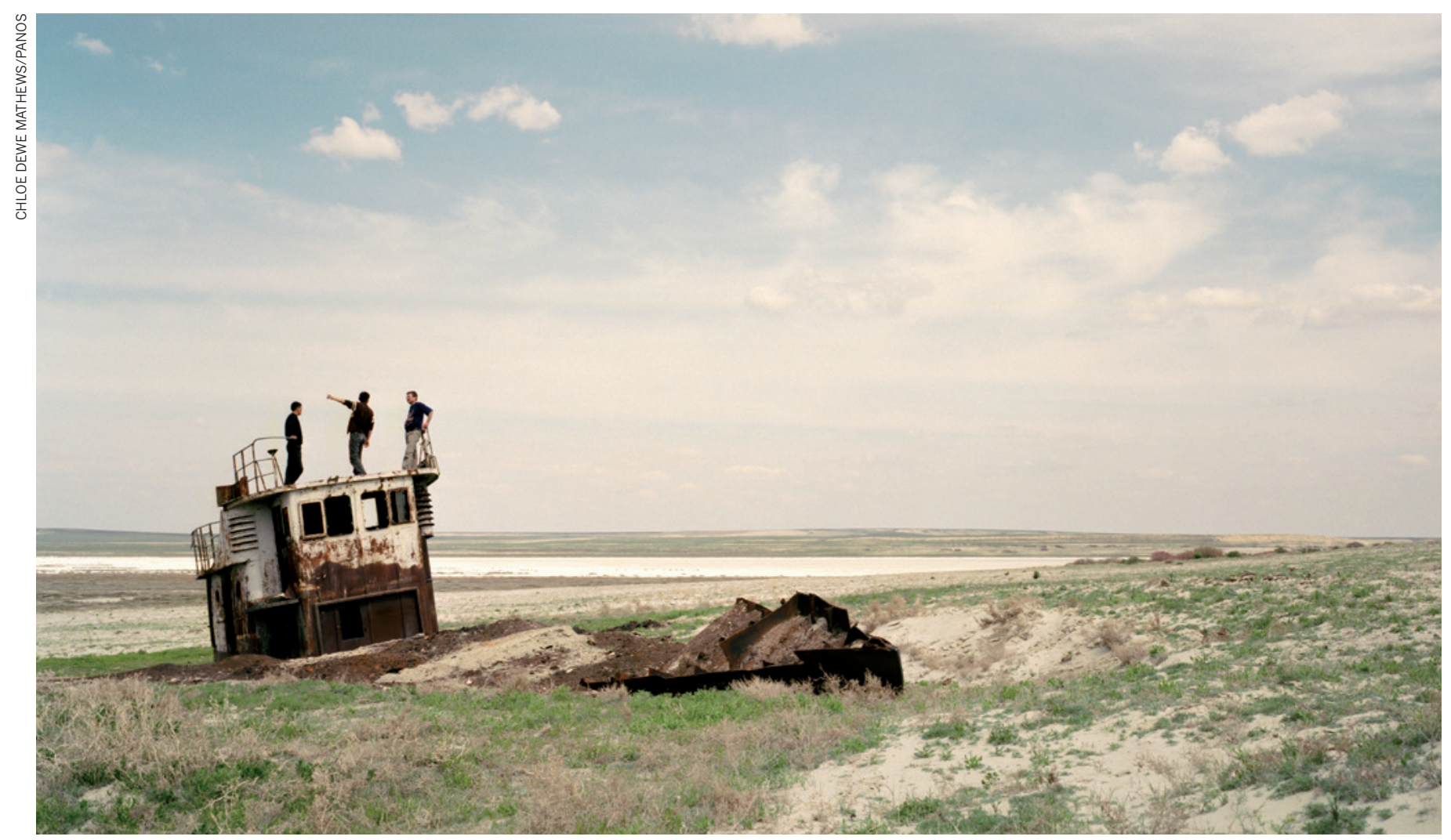

A boat rusts on the bed of the dried Aral Sea, more than $90 \%$ of which has vanished in the past 50 years.

\title{
Curb vast water use in central Asia
}

\section{Irrigation-intensive industries in former Soviet republics have sucked water bodies dry. Olli Varis calls for economic reform to ease environmental and social tensions.}

$\mathrm{S}$ hipwrecks rusting in the desert have come to symbolize the environmental havoc that has befallen the Aral Sea, which straddles Kazakhstan and Uzbekistan. More than $90 \%$ of what was once the fourth-largest lake in the world has vanished in half a century ${ }^{1-3}$. The cracked shores are symptoms of the dramatic overuse of water in central Asia. Since the 1960s, 70\% of Turkmenistan has become desert, and half of Uzbekistan's soil has become salty owing to dust blown from the dry bed of the Aral Sea ${ }^{1}$. The republics of Uzbekistan, Tajikistan, Turkmenistan, Kyrgyzstan and Kazakhstan were developed as farming states to supply produce to the former Soviet Union ${ }^{1}$. Today, they are among the highest per capita users of water in the world - on average, each Turkmen consumes 4 times more water than a US citizen, and 13 times more than a Chinese one $^{4}$ (see 'Top 20 consumers'). More than $90 \%$ of the region's water use is irrigating thirsty crops including cotton and wheat ${ }^{1,2}$.

Decades of over-extraction have nearly sucked dry the Amu Darya and Syr Darya rivers that feed the Aral Sea. Local livelihoods that rely on livestock grazing, hunting and fishing have disappeared; ecosystems in the Aral's brackish waters, deltas, coasts, steppes and fertile river valleys have collapsed ${ }^{1}$. As water bodies have vanished, the local climate has become harsher: summers bring extreme heat and violent, salty dust storms; winters 


\section{TOP 20 CONSUMERS}

Central Asian republics use disproportionately large quantities of water relative to the size of their economies and populations. Most water goes to irrigate crops grown in poor-quality soils.

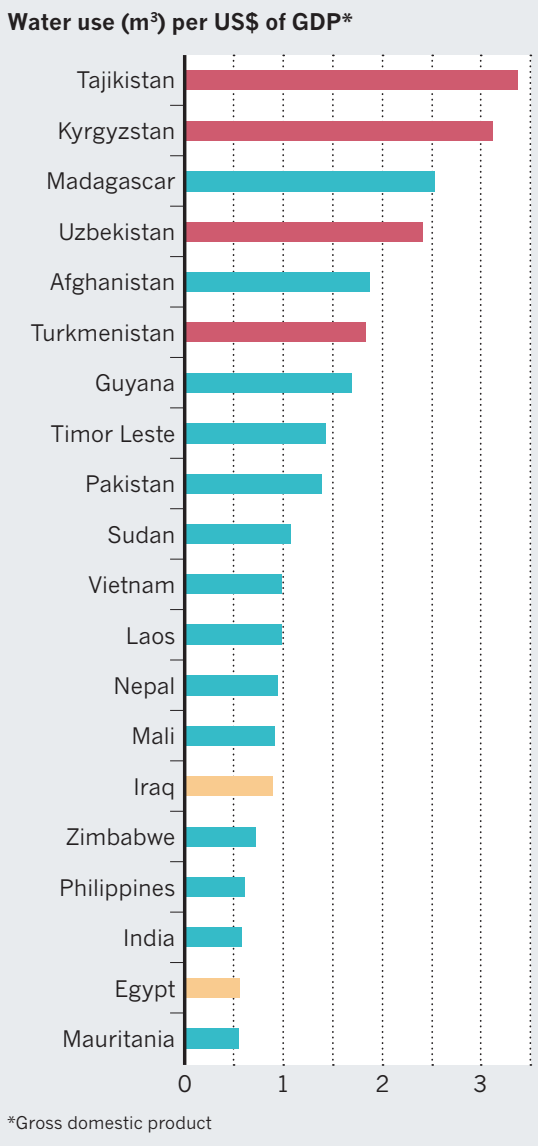

Water use $\left(\mathrm{m}^{3}\right)$ per capita

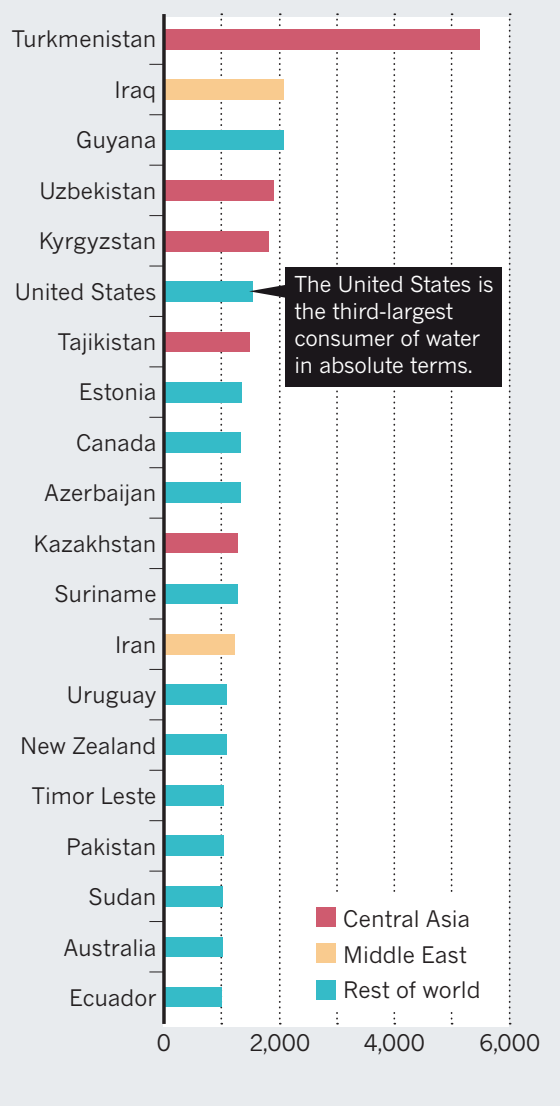

are more severely cold. The wind spreads salt and agrochemicals to farmlands hundreds of kilometres away, causing respiratory and gastroenterological diseases as well as anaemia, cancer and tuberculosis ${ }^{3,5}$.

Struggling to shake off the Soviet legacy of environmental and political crises and oligarchies, these republics are more rivals than neighbours. Because most of the region's water bodies - mainly the Syr Darya, Amu Darya and Zarafshon rivers - are shared, political tensions have grown around water access, drawing worrying parallels with similar crises in the Arab world.

The first step is to recognize that the origin of central Asia's water problems is in excessive water demand. Fixing the problem will mean developing regional industries that are less water intensive and more profitable than agriculture, by tapping human potential rather than natural resources. Unless the region's economy can be put on a more sustainable footing, the stability and security of central Asia is in danger.

\section{SHORTAGE MYTH}

Two fallacies stymie debate about water in central Asia. The first is that the region is short of water. The landscape looks dry and rivers run empty. Many analyses in the past few years ${ }^{3,5}$ have thus recommended water-conservation measures, assuming that incremental policy changes are all that can be delivered. In fact, these countries have plenty of water relative to their populations.$$
\text { "The annual availabili- }
$$

"Infact, these ties of fresh water per countries capita for the Amu have plenty of Darya (2,087 cubic water relative metres) and the Syr to their populations." Darya $\left(1,744 \mathrm{~m}^{3}\right)$ river basins ${ }^{6}$ are well above the United Nations definitions of water shortages ${ }^{7}: 1,000 \mathrm{~m}^{3}$ per capita constitutes a chronic shortage, and $1,700 \mathrm{~m}^{3}$ a moderate shortage. By comparison, Denmark has $1,128 \mathrm{~m}^{3}$ of water per capita, Germany $1,878 \mathrm{~m}^{3}$ and the United Kingdom 2,465 $\mathrm{m}^{3}$ (ref. 4).

The second fallacy is that the solution is agricultural. Most analysts propose that water should be used more efficiently on farms because it is wasted in growing low-return crops on dry lands unsuitable for agricultural use. Turkmenistan's dry climate and poor soils mean that producing a tonne of wheat takes $2,000-4,000 \mathrm{~m}^{3}$ of irrigation water, whereas in nearby northern Kazakhstan adequate rainfall and conditions mean that no irrigation is needed. Even as its land became parched, Turkmenistan's wheat yield increased ninefold between 1992 and 2007.

But the big fish swims elsewhere: the agricultural share of gross domestic product (GDP) in central Asia has almost halved since the disintegration of the Soviet Union $^{4}$. Instead, economic growth is dominated by the oil and gas industry and by urban expansion. Already, more than half of the region's population is urban and that proportion is rising.

Despite this, central Asian economies continue to focus on primary industries such as agriculture and the extraction of fossil fuels. The economic return on water is lower in central Asia than anywhere else on the planet. Turkmenistan uses nearly 3 times more water than India to produce one GDP dollar, 4 times more than Egypt, 14 times more than China and 43 times more than Spain ${ }^{4}$.

\section{RISING TENSION}

The resulting problems are greater than just stagnant economies. Disputes (see 'Troubled waters') between nations have arisen around access to shared water bodies in the Fergana Valley in the Syr Darya river basin, in the Zarafshon river basin, and in Amu Darya most notably concerning the Nurek dam and Turkmen-Uzbek rivalries on water appropriation.

These tensions are stoked by absurd projects such as the Golden Age Lake (Altyn Asyr) in the Karakum Desert ${ }^{8,9}$. Projected to cover almost half the area of the Great Salt Lake in Utah, the synthetic lake will be about six times its volume. Since 2000, Turkmenistan has been constructing it, claiming it will increase agricultural production and offer a "symbol of revival of the Turkmen land", as former president Saparmurat Niyazov (known as Turkmenbashi) put it ${ }^{9}$.

Water for the lake will be drawn from the Amu Darya river through two canals, which are being cut across about $3,200 \mathrm{~km}$ of desert ${ }^{8,9}$. Although it is unclear whether that much water can ever be sourced from the river, it is obvious that downstream, Uzbekistan will not accept those diversions and is ready to defend its water share with arms if necessary. The already serious soilsalinization problems of Turkmenistan and Uzbekistan will be greatly worsened if the project is completed.

Like most other parts of the former Soviet Union, central Asian states suffer authoritarian rule and political fragility. Soaring unemployment is leading to a mass emigration of educated people. Current figures estimate that up to one-third of working-age Tajiks are employed abroad. Ethnic, political 
and religious diversity and difficulties with boundary demarcation fuel nationalism. Internal hostilities, as in the Caucasus, Moldova and eastern Ukraine, are a threat. A full-scale regional conflict, regardless of the rise of radical religious groups, is not out of the question.

Central Asia's water crisis echoes that in the Middle East and North Africa, where political, economic and environmental issues are also intertwined. In Arab countries such as Syria, Yemen and Tunisia, water is scarce and used for low-value purposes, generating little income or investment ${ }^{10}$. Urban populations are fast-growing but ill-served by development policies focused on traditional rural and primary industries. Political and professional inertia makes change difficult.

Three main differences may make the situation in the former Soviet republics worse than in the Middle East. First, investments in the central Asian water sector are even less productive and more conflict-prone than in Arab countries. Second, water is more abundant in central Asia but environmental disasters have been more severe there than in Arab countries. Third, Arab cities absorb immigrants more successfully and grow faster than those in central Asia, where skilled workers tend to emigrate to countries outside the region, notably Russia. joint interests and competitive advantages to build a new regional economy, with wise water use at its heart. These countries could have a much more conscious role in world politics and in the global economy by looking at their complementary strengths and merging their markets.

\section{HUMAN POTENTIAL}

The human resources of central Asia are relatively untapped. The republics have essentially full adult literacy and well over
The central Asian countries must find

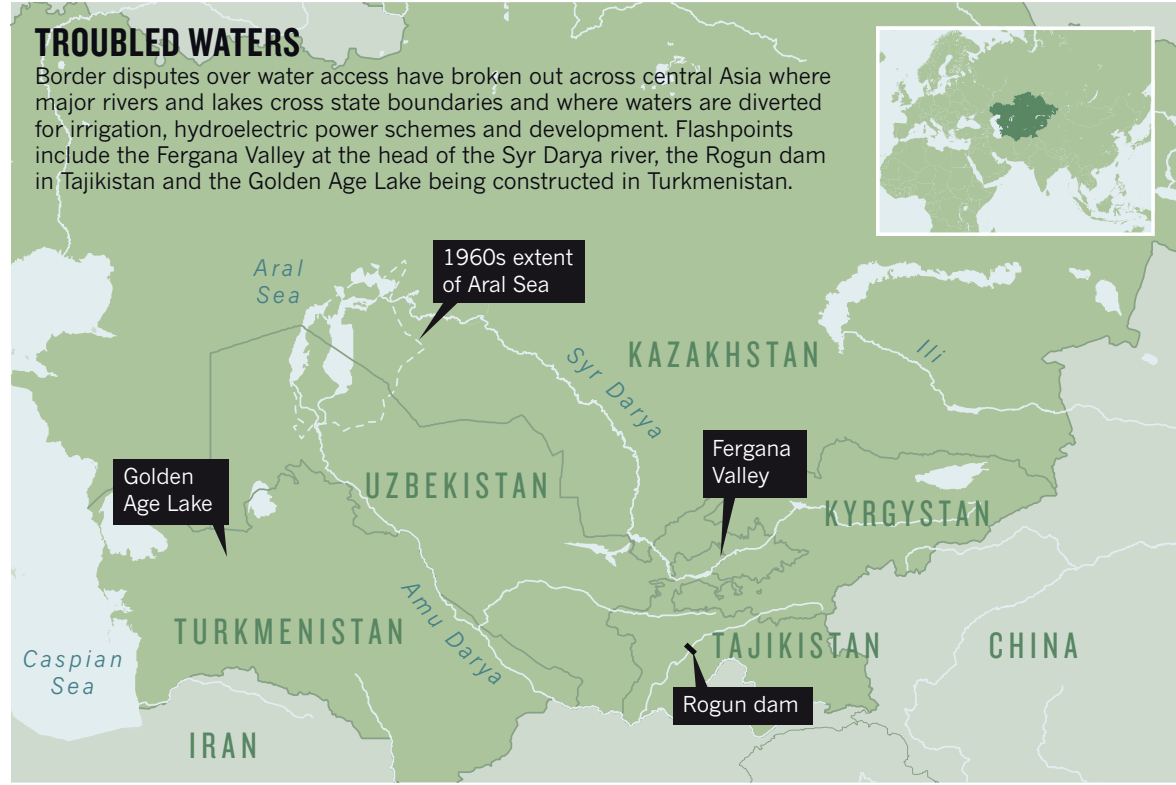

$90 \%$ of adults have secondary education ${ }^{8}$. The nations are in a favourable geographical position between diverse markets, including China, Russia, the Middle East and Europe.

Different national strengths should be exploited: Turkmenistan is rich in oil, Tajikistan and Kyrgyzstan in hydropower, for instance. Urban economies, services, manufacturing and knowledge-intensive industries should be boosted by governance reforms.

Realizing human potential would require policies to attract investments, maintain and enhance high standards of education, help industries to grow, and empower a bigger share of the population to contribute to political decision-making. Inertia may be the real bottleneck.

Experience from elsewhere abounds. Information and communication technology brings in more than one-quarter of India's export earnings; China, South

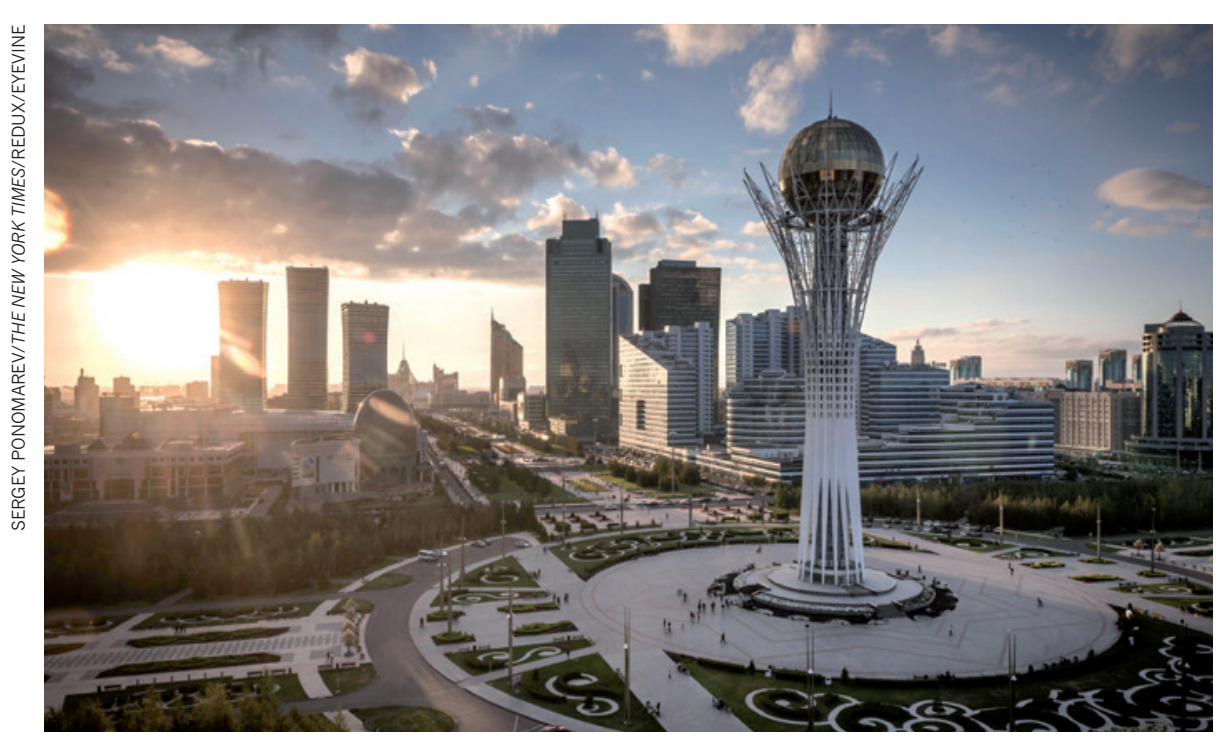

Kazakhstan's capital Astana: rapid urban expansion will influence the region's water use.
Korea, Vietnam and some other ex-Soviet states - notably Estonia - have also created knowledge-based industries almost from scratch. Such industries provide intellectually attractive, high-income jobs for the younger generation and put little strain on water resources and the environment.

International policy-makers and the water sector must refocus and look much more broadly at water's role in the region's political and economic development. That wider perspective should guide the next round of water-resources assessments, as well as toplevel international policy meetings such as the 7th World Water Forum in Daegu, South Korea, in April 2015.

The alternative could be much worse: more iron wreckage on the drylands - this time of military origin.

Olli Varis is professor of water-resources management at Aalto University, Finland. e-mail:olli.varis@aalto.fi

1. Dukhovny, V. A. \& de Schutter, J. Water in Central Asia: Past, Present, Future (CRC, 2011).

2. United Nations Economic Commission for Europe Strengthening Water Management and Transboundary Water Cooperation in Central Asia: The Role of UNECE Environmental Conventions (UNECE, 2011).

3. Granit, J. et al. Regional Water Intelligence Report Central Asia (Stockholm International Water Institute, 2010).

4. World Bank World Development Indicators (World Bank, 2013).

5. United Nations Environmental Programme Environment and Security in the Amu Darya Basin (UNEP, 2011).

6. Porkka, M., Kummu, M., Siebert, S., \& Flörke, M. Int. J. Water Resourc. Dev. 28, 455-476 (2012).

7. Falkenmark, M. Phil. Trans. R. Soc. Lond. B 352 929-936 (1997).

8. Zonn, I. S. \& Kostianoy, A. G. (eds) The Turkmen Lake Altyn Asyr and Water Resources in Turkmenistan (Springer, 2013).

9. Stone, R. Science 320, 1002-1005 (2008).

10.Varis, O. \& Abu-Zeid, K. Int. J. Water Resourc. Dev. 25, 507-522 (2009). 